\title{
THE ROLE OF THE COMMUNITY PARTICIPATION IN THE ARCHITECTURAL HERITAGE PROJECTS IN PALESTINE (COMPARATIVE STUDY)
}

\author{
Ziad M. M. Shehada ${ }^{1 *}$ \\ 1 Department of Architecture, University of Malaya, Malaysia \\ Email: Archzms@gmail.com \\ * Corresponding Author
}

\section{Article Info:}

Article history:

Received date: 25.03 .2020

Revised date: 10.06 .2020

Accepted date: 13.06 .2020

Published date: 15.06 .2020

\section{To cite this document:}

Shehada, Z. M. M. (2020). The Role of The Community Participation in The Architectural Heritage Projects in Palestine (Comparative Study). International Journal of Heritage, Art and Multimedia, 3 (9), 38-46.

DOI: $10.35631 /$ IJHAM.39004.

\begin{abstract}
:
Community participation is very important in the heritage conservation projects. It assists the people to solve their problems and allow them to preserve the legacy for the future generation. The study aims to evaluate the role of community participation in the cultural heritage projects in Palestine using Arnstein's ladder and explore the extent to which such participation contributes to the success of these projects. The researcher adopts an analytical and comparative research method to deeply understand the importance of involving the community in the conservation projects through six case studies: three inside Palestine and three outside Palestine. The study concludes that there is a distinction in the concept of community participation in conservation projects. Besides, community participation takes different forms depending on the stage of works, the request of the stakeholders, and the categories of participants. The article emphasises the necessity of activating and adopting community participation as a method for the implementation of conservation projects.
\end{abstract}

Keywords:

Heritage, Community Participation, Palestine

\section{Introduction}

Cultural heritage is a very important historical, geographical and civilizational component in Palestine; its significance is not only at the national level but also at the international level. UNESCO has inscribed recently three properties on the world heritage list, while thirteen Sites were inscribed on the tentative list (Meskell, 2018). Concerning architectural and archaeological heritage in Palestine, many of these sites have not been fully excavated so far. Many dangers and risks have threatened the cultural heritage in general and the architectural heritage in particular (Dawson, James, \& Nevell, 2019; Dweik, 2014). Israel is trying to erase everything that indicates the heritage and civilization of Palestine and everything that attributes Copyright $\odot$ GLOBAL ACADEMIC EXCELLENCE (M) SDN BHD - All rights reserved 
to its past and heritage (Khalidi, 2010). Despite enacting laws and legislations, the Palestinian Authority cannot apply and enforce these laws because of the occupation (Bowe, 2014; Carstens, Carstens, \& Varner, 2020). Palestinians, thus, are most passionate about and much bound to their culture, civilization and heritage in different social aspects (Ghadban, Hassan, Aboudi, \& Khateeb, 2013).

\section{Literature Review}

The concept of community participation, depending on the country's system, varies from one country to another. However, the United Nations document (1981: 5) defined community participation as "The creation of opportunities to enable all members of a community to actively contribute to and influence the development process and to share equitably in the fruits of development" (Roy, 2002).

This definition, according to the report, is consistent with the inclusion of the democratic and voluntary use of people in:

- Contributing to development efforts.

- Fair participation in results and benefits.

- Decision-making concerning established goals, policies, planning and inclusion of economic and social development programs.

There are two models of community participation: Top-Down Model and Partnership Model; each differs in respect with rules, where either the decision-makers or the affected community controls and implements the program (McKay \& Paikoff, 2012; Rok, 2009). Some scholars relate the achievement of specific development goals with the first model and relates large direct participation with sources to the second model, at the same time other scholars suggest that it could be an overlap between the two models (Islam, 2018). While the top-down model explains that the government or the decision-makers provide the community and makes decisions; the partnership model enhances the collaboration between the government and communities to work together in the planning and design, which positively affects the sustainability and long-term results (Moatasim, 2019).

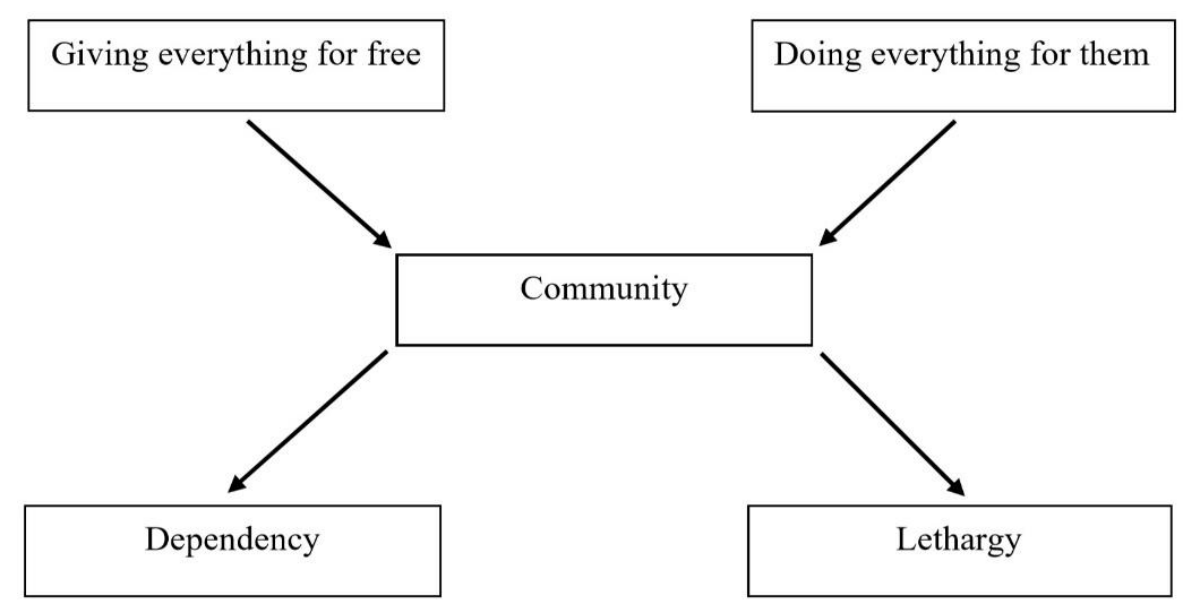

Figure 1: Top-Down Model

Source: (Spellerberg et al., 2012) 


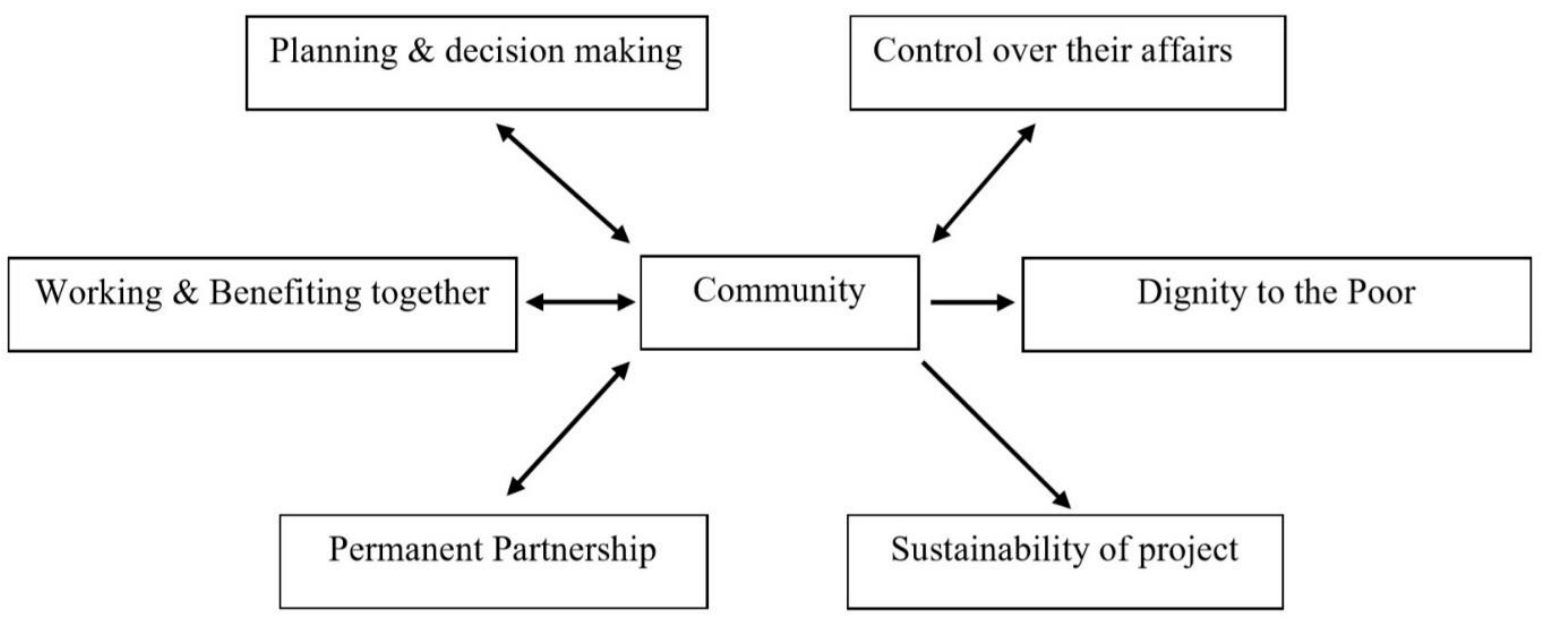

Source: (Anderson \& McFarlane, 2010)

Figure 2: Partnership Model

\section{Case Studies}

The researcher selected three projects from inside Palestine: (1) Palaces of Arraba in the city of Jenin which is traditionally associated with the ancient fortified Canaanite City of Arubboth and one of the famous heritage projects in Palestine. (2) African district in Jerusalem that is chosen based on its historical and architectural value as one of the oldest lodges for pilgrims; and (3) Hebron rehabilitation committee, which carries out projects in architectural preservation targeting all areas of the old city from housing to historical buildings to basic infrastructure.

The researcher chose other three projects from outside Palestine: The first is Al-Azhar park \& Darb al-Ahmar located in Cairo and listed as one of the world's sixty great public spaces, due to its architectural and historical value, the project was funded by Aga Khan Award for Architecture (Catalani et al., 2018; Jodidio, 2011). The second project is Al-Omari Grand Mosque in Beirut built during the rule of Omar Bin Al Khattab and conserved in 2004. The third project is Asilah City, which was well-preserved and goes back to $15^{\text {th }} \& 16$ th centuries (Honnor, 2012). The city has been heavily restored; its buildings have been typically painted white, blue, and green.

\section{Analytical Comparison Among the Projects Inside and Outside Palestine}

The researcher collected secondary data from books, research papers, and Internet sites. The researcher collected primary data by visiting the sites where he distributed the questionnaire and interviewed the stakeholders. The research analysis includes five categories that compare the research's different topics and perspectives.

\section{Comparison According to Community Participation Request}

It is important to know who requests the community to participate in the projects, which can guide participants to a better future, and which can help them understand the keys of success. The request of the community participation is divided into three categories; request by the donors, request by the consultant, or participation undergoes under the community pressure. 


\begin{tabular}{|c|c|c|c|c|}
\hline \multicolumn{5}{|c|}{ Table 1: Comparison According to Request Community Participation } \\
\hline \multicolumn{2}{|c|}{ Project } & community participation request by \\
\cline { 2 - 5 } \multicolumn{7}{|c|}{$\begin{array}{c}\text { Inside } \\
\text { Palestine }\end{array}$} & Palaces of Arraba & & $\sqrt{ }$ & \\
\cline { 2 - 5 } & African district & & $\sqrt{ }$ & \\
\cline { 2 - 5 } & Hebron Rehabilitation Committee & & $\sqrt{ }$ & \\
\hline \multirow{2}{*}{$\begin{array}{c}\text { Outside } \\
\text { Palestine }\end{array}$} & Al-Azhar park \& Darb al-Ahmar & $\sqrt{ }$ & $\sqrt{ }$ & \\
\cline { 2 - 5 } & Great Omari Mosque & $\sqrt{ }$ & $\sqrt{ }$ \\
\cline { 2 - 5 } & Asilah city & & $\sqrt{ }$ \\
\hline
\end{tabular}

Source: (The researcher)

From the table above, it is noticed that the community participation is required by the consultant in the majority of the projects whether inside or outside Palestine as this culture has not been spread among the stakeholders yet. Besides, the positive point is that the donors agree to involve the public in their projects, which contribute to the success of the project. The results above indicate that the public should practice the pressure on the consultant and donors to be involved in any project implemented in their area in order to participate in making decisions. The great Omari mosque is a good example about how the public press of the stakeholders considers their decisions.

\section{Comparison According to the Participants' Categories}

The researcher divided the stakeholders into nine categories; this division includes individuals, groups and organizations. The next table shows the category of participants in each project.

\begin{tabular}{|c|c|c|c|c|c|c|}
\hline \multicolumn{7}{|c|}{ Table 2: Comparison According to the Participants' Categories } \\
\hline Project & \multicolumn{3}{|c|}{ Inside Palestine } & \multicolumn{3}{|c|}{ Outside Palestine } \\
\hline Categories & $\begin{array}{l}\text { Palaces } \\
\text { of Arraba }\end{array}$ & $\begin{array}{l}\text { African } \\
\text { district }\end{array}$ & $\begin{array}{c}\text { Hebron } \\
\text { Rehabilitation } \\
\text { Committee }\end{array}$ & $\begin{array}{l}\text { Al-Azhar park \& } \\
\text { Darb al-Ahmar }\end{array}$ & $\begin{array}{c}\text { Great } \\
\text { Omari } \\
\text { Mosque }\end{array}$ & $\begin{array}{c}\text { Asilah } \\
\text { city }\end{array}$ \\
\hline Owners & $\sqrt{ }$ & & $\sqrt{ }$ & $\sqrt{ }$ & & $\sqrt{ }$ \\
\hline Users & $\sqrt{ }$ & $\sqrt{ }$ & $\sqrt{ }$ & $\sqrt{ }$ & $\sqrt{ }$ & $\sqrt{ }$ \\
\hline Donors & $\sqrt{ }$ & & & & $\sqrt{ }$ & \\
\hline Investors & & & & & & $\sqrt{ }$ \\
\hline $\begin{array}{c}\text { Governmental } \\
\text { Organization }\end{array}$ & $\sqrt{ }$ & & & & & \\
\hline NGOs & $\sqrt{ }$ & & $\sqrt{ }$ & & $\sqrt{ }$ & \\
\hline $\begin{array}{c}\text { Local } \\
\text { Committees }\end{array}$ & & $\sqrt{ }$ & & $\sqrt{ }$ & & \\
\hline Experts & & & $\sqrt{ }$ & & & $\sqrt{ }$ \\
\hline Public & $\sqrt{ }$ & & & $\sqrt{ }$ & $\sqrt{ }$ & $\sqrt{ }$ \\
\hline
\end{tabular}

Source: (The researcher)

The community participation doesn't mean that the public only can participate in the projects but the experts, NGOs, local committees and so on, any of who can give an opinion to come up to the best solution. The beneficiaries of any projects have to participate in the project at its early stages, otherwise they will not feel satisfied and will act in a negative role. The table shows that the participation of the stakeholders varies according to the project, however, the users involved in all projects did not have a broad participation from all categories of stakeholders as they are still in their early stages of this concept. 


\section{Comparison According to the Stages of Work}

In the heritage conservation projects, there are many stages of work starting from preparing the site and documents until finishing the project and maintenance. The research investigates the position of community participation in these stages and lack of this participation in such projects.

\begin{tabular}{|c|c|c|c|c|c|c|c|}
\hline & & Table 3: C & mparison Accol & ding to $\mathrm{Th}$ & Stages of Wo & & \\
\hline & roject & & & Stag & of work & & \\
\hline & & $\begin{array}{l}\text { Preparing } \\
\text { and } \\
\text { selecting } \\
\text { the site }\end{array}$ & $\begin{array}{c}\text { Documentation } \\
\text { and collecting } \\
\text { the date }\end{array}$ & $\begin{array}{l}\text { Choosing } \\
\text { the task }\end{array}$ & $\begin{array}{c}\text { Conservation } \\
\text { plan and } \\
\text { design }\end{array}$ & Implementation & $\begin{array}{l}\text { Follow- } \\
\text { up and } \\
\text { operation }\end{array}$ \\
\hline $\begin{array}{c}\text { Inside } \\
\text { Palestine }\end{array}$ & $\begin{array}{c}\text { Palaces of } \\
\text { Arraba }\end{array}$ & & $\sqrt{ }$ & $\sqrt{ }$ & $\sqrt{ }$ & & $\sqrt{ }$ \\
\hline & $\begin{array}{c}\text { African } \\
\text { district }\end{array}$ & $\sqrt{ }$ & $\sqrt{ }$ & & & $\sqrt{ }$ & $\sqrt{ }$ \\
\hline & $\begin{array}{c}\text { Hebron } \\
\text { Rehabilitation } \\
\text { Committee }\end{array}$ & & $\sqrt{ }$ & & $\sqrt{ }$ & & $\sqrt{ }$ \\
\hline $\begin{array}{l}\text { Outside } \\
\text { Palestine }\end{array}$ & $\begin{array}{c}\text { Al-Azhar } \\
\text { park and } \\
\text { Darb al- } \\
\text { Ahmar }\end{array}$ & & $\sqrt{ }$ & $\sqrt{ }$ & $\sqrt{ }$ & $\sqrt{ }$ & $\sqrt{ }$ \\
\hline & $\begin{array}{l}\text { Great Omari } \\
\text { Mosque }\end{array}$ & $\sqrt{ }$ & & $\sqrt{ }$ & & $\sqrt{ }$ & \\
\hline & Asilah city & & $\sqrt{ }$ & $\sqrt{ }$ & & $\sqrt{ }$ & $\sqrt{ }$ \\
\hline
\end{tabular}

Source: (The researcher)

The above table shows that the community role can support the project fully or partially and at any stage. This contribution varies from project to another depending on its nature. In addition, the participation might be from the public in some stages and from the experts in other stages, which will achieve inclusiveness, complementarity and accuracy. The community participation can be applied in each stage of the cultural heritage projects as proved above. As well, no project has community participation in all stages of the work whether inside or outside Palestine. It is also noticed that while outside Palestine all projects have participation at the implementation stage, inside Palestine there is less participation and implementation.

\section{Comparison According to Various Topics Related to Stakeholders' Participation}

Many other topics have been discussed with the stakeholders to know their opinions about the participation in the conservation projects. These topics have a significant indication for the government and projects' leaders to activate the community participation and involve the community not only during project implementation but also before and after. 


\begin{tabular}{|c|c|c|c|c|c|c|}
\hline \multicolumn{7}{|c|}{ Figure 4: Topics Related to Stakeholders' Participation } \\
\hline \multicolumn{2}{|c|}{ Project } & $\begin{array}{c}\text { Provide } \\
\text { information }\end{array}$ & $\begin{array}{c}\text { Receive } \\
\text { information }\end{array}$ & Training & Operation & $\begin{array}{c}\text { Get } \\
\text { experience }\end{array}$ \\
\hline \multirow{3}{*}{$\begin{array}{c}\text { Inside } \\
\text { Palestine }\end{array}$} & $\begin{array}{c}\text { Palaces of } \\
\text { Arraba }\end{array}$ & $\sqrt{ }$ & $\sqrt{ }$ & & $\sqrt{ }$ & \\
\hline & $\begin{array}{c}\text { African } \\
\text { district }\end{array}$ & $\sqrt{ }$ & $\sqrt{ }$ & & & \\
\hline & $\begin{array}{c}\text { Hebron } \\
\text { Rehabilitation } \\
\text { Committee }\end{array}$ & $\sqrt{ }$ & $\sqrt{ }$ & & & \\
\hline \multirow{3}{*}{$\begin{array}{l}\text { Outside } \\
\text { Palestine }\end{array}$} & $\begin{array}{c}\text { Al-Azhar } \\
\text { park \& Darb } \\
\text { al-Ahmar }\end{array}$ & $\sqrt{ }$ & $\sqrt{ }$ & $\sqrt{ }$ & $\sqrt{ }$ & $\sqrt{ }$ \\
\hline & $\begin{array}{l}\text { Great Omari } \\
\text { Mosque }\end{array}$ & & & & $\sqrt{ }$ & \\
\hline & Asilah city & $\sqrt{ }$ & $\sqrt{ }$ & & $\sqrt{ }$ & \\
\hline \multicolumn{2}{|c|}{ Project } & $\begin{array}{l}\text { Support } \\
\text { Decision }\end{array}$ & $\begin{array}{c}\text { Make } \\
\text { Decision }\end{array}$ & Suggestions & Consultation & $\begin{array}{c}\text { Project } \\
\text { financing }\end{array}$ \\
\hline \multirow{3}{*}{$\begin{array}{c}\text { Inside } \\
\text { Palestine }\end{array}$} & $\begin{array}{c}\text { Palaces of } \\
\text { Arraba }\end{array}$ & $\sqrt{ }$ & & $\sqrt{ }$ & $\sqrt{ }$ & \\
\hline & $\begin{array}{l}\text { African } \\
\text { district }\end{array}$ & $\sqrt{ }$ & $\sqrt{ }$ & $\sqrt{ }$ & $\sqrt{ }$ & \\
\hline & $\begin{array}{c}\text { Hebron } \\
\text { Rehabilitation } \\
\text { Committee } \\
\end{array}$ & & & & $\sqrt{ }$ & \\
\hline \multirow{3}{*}{$\begin{array}{l}\text { Outside } \\
\text { Palestine }\end{array}$} & $\begin{array}{c}\text { Al-Azhar } \\
\text { park \& Darb } \\
\text { al-Ahmar }\end{array}$ & $\sqrt{ }$ & & $\sqrt{ }$ & $\sqrt{ }$ & \\
\hline & $\begin{array}{l}\text { Great Omari } \\
\text { Mosque }\end{array}$ & & $\sqrt{ }$ & & & \\
\hline & Asilah city & $\sqrt{ }$ & & $\sqrt{ }$ & $\sqrt{ }$ & $\sqrt{ }$ \\
\hline
\end{tabular}

Source: (The researcher)

The topics related to the stakeholders vary due to the audience culture, abilities, and availability. The table demonstrates the topics related to the Stakeholders' participation in the projects inside and outside Palestine. It is noted that the projects have a good participation in term of information (provision or reception); the other topics are still at the early stages and vary from project to another.

\section{Discussion}

Due to the previous analysis, the researcher used Arnstein's ladder to show the participation ranging from high to low. "The ladder is a guide to seeing who has power when important decisions are being made. It has survived for so long because people continue to confront processes that refuse to consider anything beyond the bottom rungs" 


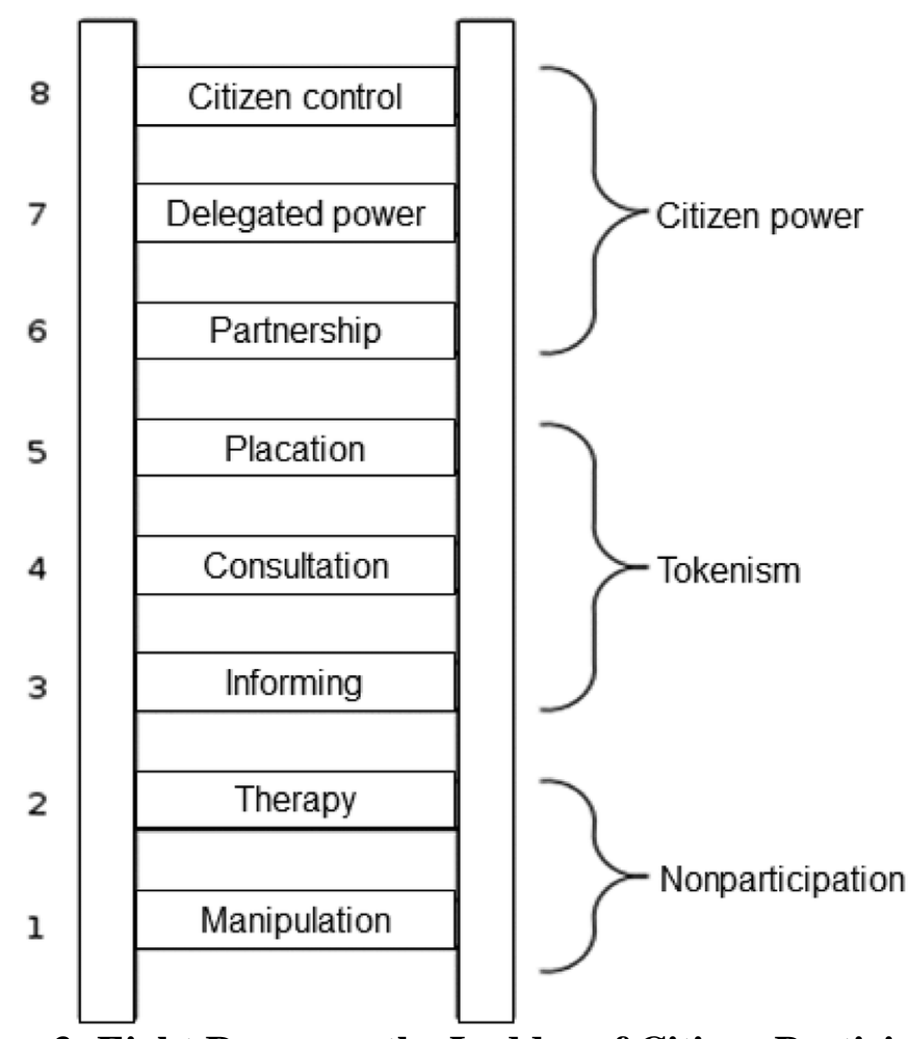

Source: (Sulemana, 2012)

Figure 3: Eight Rungs on the Ladder of Citizen Participation

The researcher applied the Arnstein ladder on the community participation in the previous projects to evaluate the degree of participation, and the result was as follow:

\begin{tabular}{|c|c|c|c|}
\hline \multicolumn{4}{|c|}{ Table 5: Evaluation of Community Participation Depend on Arnstein Ladder } \\
\hline \multirow{3}{*}{ Inside Palestine } & Project & Degree & Remarks \\
\cline { 2 - 4 } & Palaces of Arraba & 4,5 & Average \\
\cline { 2 - 4 } & African district & 5 & Close to Partnership \\
\cline { 2 - 4 } & Hebron Rehabilitation Committee & 1 & Very low \\
\hline \multirow{4}{*}{ Outside Palestine } & Al-Azhar park and Darb al-Ahmar & 6 & In general \\
\cline { 2 - 4 } & Great Omari Mosque & 8 & Citizen Control \\
\cline { 2 - 4 } & Asilah city & 3,4 & $\begin{array}{c}\text { Between Informing and } \\
\text { consultation }\end{array}$ \\
\hline
\end{tabular}

Source: (The researcher)

It is noticed from table 5 that the participation of the community in the projects varies from one to one; where the best is the Great Omari Mosque as the community was involved in the majority of the projects' stages, so it is considered one of the most successful projects, while the worst is the projects under Hebron Rehabilitation Committee. Such research with no doubt will encourage the decision makers to understand the equation where the more society participation, the higher probability of success.

\section{Conclusion}

The Palestinians have suffered under the Israeli occupation since 1948, so most of the conservation projects in Palestine are implemented by external funding and support. The Palestinians can invest the local potentials and capacities to set foundations of sustainable development through two ways; transforming the external aiding to support the local skills, 
capabilities and existing knowledge; and activating the community participation at all stages of conservation projects in order to increase the awareness and preservation of the achievements in the future.

This study evaluates the society's participation in architectural and urban conservation projects from the applied theme. The study analyses the interaction of the community in the projects by varying degrees of community participation. This has been done by analysing case studies from outside Palestine, compared with other cases in Palestine. The study found that community participation contributed to the success of these projects in varying proportions.

The study concludes that there is a difference in the concept of community participation in conservation projects, which eventually include citizens. This thus shows that there is no citizen control power among the implementation of projects. The study also concludes that the diversity of the needed objectives of community participation differentiates accordingly with each case. Besides, keeping the conservation of architectural and urban heritage alive requires activation and adoption of the community participation as a method for implementing any project.

\section{References}

Anderson, E. T., \& McFarlane, J. M. (2010). Community as Partner: Theory and Practice in Nursing: Wolters Kluwer Health/Lippincott Williams \& Wilkins.

Bowe, M. (2014). Heritage Studies: Stories in the Making: Cambridge Scholars Pub.

Carstens, A. M., Carstens, R. G. U. L. C. L. A. M., \& Varner, E. (2020). Intersections in International Cultural Heritage Law: Oxford University Press.

Catalani, A., Nour, Z., Versaci, A., Hawkes, D., Bougdah, H., Sotoca, A., . . Trapani, F. (2018). Cities' Identity Through Architecture and Arts: Proceedings of the International Conference on Cities' Identity through Architecture and Arts (CITAA 2017), May 1113, 2017, Cairo, Egypt: CRC Press.

Dawson, M., James, E., \& Nevell, M. (2019). Heritage Under Pressure - Threats and Solution: Studies of Agency and Soft Power in the Historic Environment: Oxbow Books.

Dweik, G. J. (2014). Architectural heritage in the city of Hebron and the rehabilitation of the historical centre. WIT Transactions on Ecology and the Environment, 191, 1103-1114. doi:10.2495/SC140932

Ghadban, S., Hassan, R., Aboudi, O., \& Khateeb, Y. (2013). The development of an interactive virtual environment for hisham palace in jericho, palestine. Archnet-IJAR, 7(2), 118135. Retrieved from https://www.scopus.com/inward/record.uri?eid=2-s2.084886791990\&partnerID=40\&md5=b04bba0430d362b3f683d8329a684f7a

Honnor, J. (2012). Morocco Footprint Handbook: Footprint Handbooks.

Islam, M. R. (2018). Social Research Methodology and New Techniques in Analysis, Interpretation, and Writing: IGI Global.

Jodidio, P. (2011). The Aga Khan Historic Cities Programme: Strategies for Urban Regeneration: Prestel.

Khalidi, R. (2010). Palestinian Identity: The Construction of Modern National Consciousness: Columbia University Press.

McKay, M. M., \& Paikoff, R. L. (2012). Community Collaborative Partnerships: The Foundation for HIV Prevention Research Efforts: Taylor \& Francis.

Meskell, L. (2018). A Future in Ruins: UNESCO, World Heritage, and the Dream of Peace: Oxford University Press.

Moatasim, F. (2019). Informality Materialised: Long-term Temporariness as a Mode of Informal Urbanism. Antipode, 51(1), 271-294. doi:10.1111/anti.12434 
Rok, B. (2009). People and skills ethical context of the participative leadership model: Taking people into account. Corporate Governance, 9(4), 461-472. doi:10.1108/14720700910985007

Roy, I. (2002). Community, Organisation and Representation: Implications for Development. Economic and Political Weekly, 37(35), 3591-3595. Retrieved from www.jstor.org/stable/4412545

Spellerberg, I., Fogel, D. S., Fredericks, S. E., Harrington, L. M. B., Proto, M., \& Wouters, P. (2012). Measurements, Indicators, and Research Methods for Sustainability: Berkshire Publishing Group.

Sulemana, M. N., Ibrahim. (2012). Participatory planning: ending the controversies. European Journal of Social Sciences, 28(1), 24-34. Retrieved from http://eprints.utm.my/id/eprint/47357/ http://dx.doi.org/Participatory planning: Ending the controversies 